\title{
REGIONAL ECONOMIC DEVELOPMENT IN CHINA
}


The Saw Centre for Financial Studies was established at the National University of Singapore on 1 December 2003. The Centre is named after a distinguished NUS alumnus Professor Saw Swee-Hock, whose generous endowed gift has enabled the founding of this Centre. The Saw Centre is situated within the vibrant community of the renowned NUS Business School.

The Saw Centre's purpose is to conduct quality research, educational activities and training programmes related to the financial services industry in the Asia Pacific region. With the resources of the university and active contribution from industry professionals, it is a resource centre that will benefit both academics and practitioners.

The Saw Centre also hosts visiting academics with the Department of Finance at the NUS Business School for the purpose of teaching and research.

The East Asian Institute (EAI) was set up in April 1997 as an autonomous research organization under a statute of the National University of Singapore. It is the successor of the former Institute of East Asian Political Economy (IEAPE), which was itself the successor of the Institute of East Asian Philosophies (IEAP), originally established by Dr Goh Keng Swee in 1983 for the study of Confucianism. The main mission of EAI is to promote academic and policy-oriented research on contemporary China, including Hong Kong, Taiwan and Macau, and other East Asian economies. The long-term vision of EAI is to develop into the region's foremost research institution on East Asian development, with a strong focus on China. For more information on EAI, please visit <www.eai.nus.edu.sg>.

The Institute of Southeast Asian Studies (ISEAS) was established as an autonomous organization in 1968. It is a regional centre dedicated to the study of socio-political, security and economic trends and developments in Southeast Asia and its wider geostrategic and economic environment. The Institute's research programmes are the Regional Economic Studies (RES, including ASEAN and APEC), Regional Strategic and Political Studies (RSPS), and Regional Social and Cultural Studies (RSCS).

ISEAS Publishing, an established academic press, has issued almost 2,000 books and journals. It is the largest scholarly publisher of research about Southeast Asia from within the region. ISEAS Publishing works with many other academic and trade publishers and distributors to disseminate important research and analyses from and about Southeast Asia to the rest of the world. 

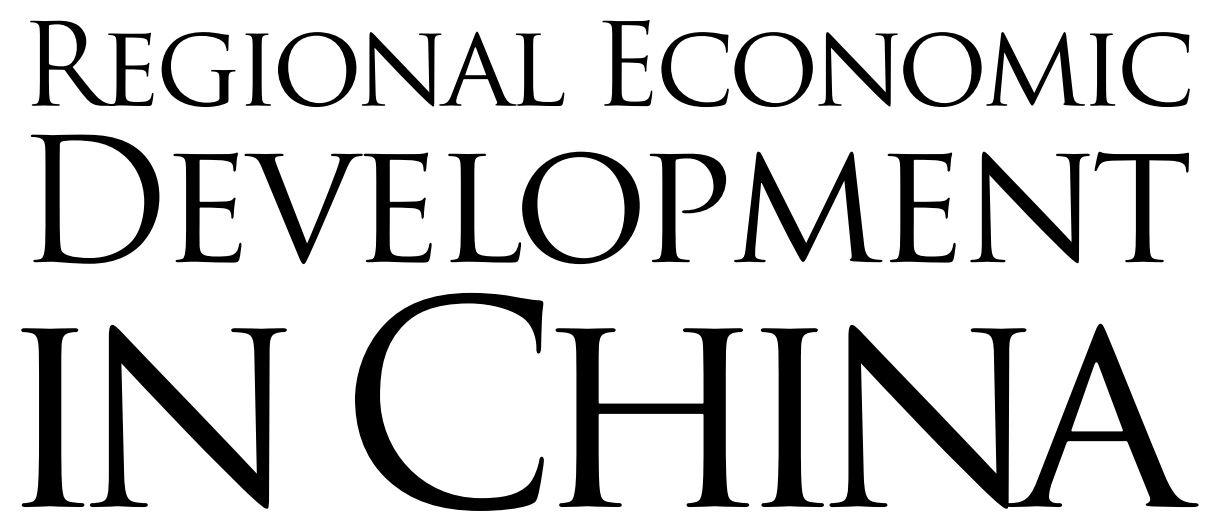

EDITED BY

SAW SWEE-HOCK AND JOHN WONG 
First published in Singapore in 2009 by ISEAS Publishing

Institute of Southeast Asian Studies

30 Heng Mui Keng Terrace

Pasir Panjang

Singapore 119614

E-mail: publish@iseas.edu.sg

Website: <http://bookshop.iseas.edu.sg>

jointly with

Saw Centre for Financial Studies

NUS Business School

National University of Singapore

BIZ 2 Building, \#04-01

1 Business Link

Singapore 117592

and

East Asian Institute

National University of Singapore

469A Bukit Timah Road,

Tower Block \#06-01

Singapore 259770

All rights reserved. No part of this publication may be reproduced, stored in a retrieval system, or transmitted in any form or by any means, electronic, mechanical, photocopying, recording or otherwise, without the prior permission of the Institute of Southeast Asian Studies.

(C) 2009 Institute of Southeast Asian Studies, Singapore

The responsibility for facts and opinions in this publication rests exclusively with the authors and their interpretations do not necessarily reflect the views or the policy of the publisher or its supporters.

\section{ISEAS Library Cataloguing-in-Publication Data}

Regional economic development in China / edited by Saw Swee-Hock and John Wong.

1. Economic development-China.

2. China-Economic policy-1976-

I. Saw, Swee-Hock, 1931-

II. Wong, John C. H., 1939-

HC428 R33

2009

ISBN: 978-981-230-941-9 (hard cover)

ISBN: 978-981-230-942-6 (PDF)

This book is meant for educational and learning purposes. The author(s) of the book has/have taken all reasonable care to ensure that the contents of the book do not violate any existing copyright or other intellectual property rights of any person in any manner whatsoever. In the event the author(s) has/have been unable to track any source and if any copyright has been inadvertently infringed, please notify the publisher in writing for corrective action.

Typeset by International Typesetters Pte Ltd Printed in Singapore by Utopia Press Pte Ltd 